\title{
A study on gender differences influencing on online buying
}

\author{
Amirnima Negahdari*
}

PhD in Business Management and Economics, Yerevan state university

\begin{tabular}{l}
\hline C H R O N I C L E \\
\hline Article history: \\
Received March 24, 2014 \\
Accepted 20 September 2014 \\
Available online \\
September 272014 \\
\hline Gender difference \\
Customer satisfaction \\
E-satisfaction \\
E-commerce \\
Online shopping \\
Online consumer behavior
\end{tabular}

\section{A B S T R A C T}

\begin{abstract}
Recently, the diffusion of the Internet as a retail and distribution channel has undergone a great growth. This paper presents an empirical investigation on the effects of gender differences on online buying. The study explored gender differences among 13 factors concerning the internet buyer. With regard to factors and consistent with Hypothesis and sub hypothesis, differences were detected across genders using t-student tests and the findings were in alignment with the ANOVA test. For data collection and final testing of the E-SAT model a questionnaire was designed and distributed among 100 randomly people who resided in Iran. The analysis show that merchandising, security and company items gained more scores for men than women in online shopping.
\end{abstract}

\section{Introduction}

Recently, the diffusion of the Internet as a retail and distribution channel has undergone a great growth and we have faced a global market with over 2 billion people and Internet grows $480.4 \%$ from 2000 to 2011 (Internet World Stats, 2011). This growth of the Internet has provoked changes in the way consumers acquire information about products, which is an essential stage of the shoppingdecision process (Engel et al., 1995). Searching for commercial information is one of the most performed activities in the Internet. Specifically, $89.3 \%$ of purchasers and $45.2 \%$ of non-purchasers use the Internet as the main source for acquiring information (AECE, 2008). Swaminathan et al. (1999) reported that male internet buyers were more convenience oriented and less motivated by social interaction than women internet buyers. Alreck and Settle (2002) indicated that women had positive attitudes towards shopping and men prefer shopping via internet. The Internet allows for the online exchange of value, without geographical or time restrictions, between firms and partners, customers, suppliers, and employees. This online relationship is referred to as electronic or ecommerce (Lynch \& Rose, 1993). E-commerce, in summing two definitions presented by Kalakota and Whinston (1996) and it is considered as any business transaction where one or more of the processes required to complete the transaction happens electronically or with the assistance of electronic tools, private networks, direct link telephone systems, and last but not least the Internet. E*Corresponding author. Tel: +989121433044, +982122328612 
commerce also incorporates all ancillary activities related to an online transaction such as shopping, ordering, delivery, payment and customer support functions. Since its birth in the 1970s, e-commerce has grown to involve many complex relationships.

These include business-to-business (B2B), business-to-consumer (B2C), consumer-to-consumer $(\mathrm{C} 2 \mathrm{C})$, Consumer-to-business (C2B), as well as non-business and intra business relationships. This study focuses on the B2C relationship, which is defined as traditional retailing transactions with individual shoppers (Kalakota \& Whinston 1996). While considerable research has investigated the drivers of service quality and satisfaction in the offline environment (Zeithaml, 2000), a small, but growing body of research has examined the drivers in the online environment (Francis \& White 2002; Donthu, 2001; Loiacono et al., 2002; Srinivasan et al., 2002; Zeithaml et al., 2000).

This is not surprising considering both the newness and importance of the field. One of the consequences of "newness" is that research on the basic questions - what drives online satisfaction and retention - is still in the exploratory stage as both theory and empirical investigations are emerging. From a broad perspective, the Internet is a new technology and Web site satisfaction will be driven by ease of use and usefulness (Davis 1989). As noted by Davis (1989), these two concepts are predominant in predicting how much consumers will be using computer technologies. The ability to easily navigate a Web site and its perceived value may influence on both usage level and satisfaction. By extension, satisfaction in the online environment may also be driven by consumer benefits in using self-service technologies. According to Van Riel et al. (2001), these benefits include convenience (Meuter et al., 2000; Frederick \& Schefter 2000; Zeithaml et al., 2000), saving time and money (Meuter et al., 2000), avoiding interpersonal interaction (Meuter et al., 2000) and being in control (Bauer et al., 2002).

Chiu et al. (2005) examined Four exogenous constructs -namely, personal awareness of security, personal innovativeness, perceived ease of purchasing, and perceived usefulness - have not only direct influences on attitudes and online purchase intentions, but also have indirect influences on online purchase intentions through the mediation of attitudes. The influences of personal innovativeness and perceived usefulness on attitudes and online purchase intentions are similar for males and females. The influences of personal awareness of security on both attitudes and online purchase intentions are strong for males, while no such effects exist for females. The influences of perceived ease of purchasing on both attitudes and online purchase intentions are stronger for females than for males. Fig. 1 demonstrates the structure of their proposed model.

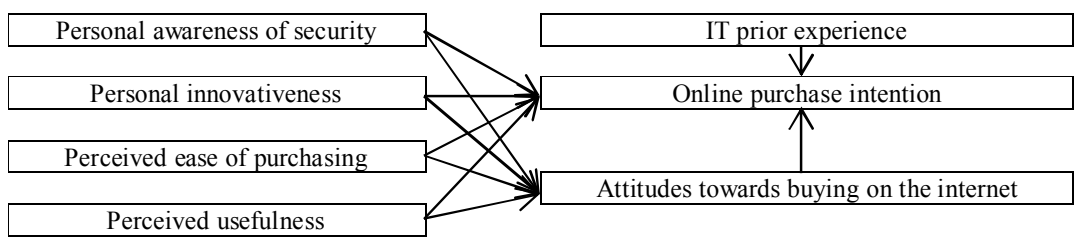

Fig. 1. The proposed model by Chiu et al. (2005)

If we take into account the sample as a whole, it was not possible to find any interaction effect of the three elements that influenced significantly their perceptions. However, taking into account the moderating role of the individual's gender, we could say that there were different combinations, which could lead to an effective product presentation. On the one hand, high quality pictures with a large size are the best combination for females. For males, presenting the product with a large size, high quality and the possibility of movement was the most preferred alternative. In this sense, we note that, when evaluating a website of electronic products, females search for an adequate product picture, with high 
levels of size and quality. In addition, males prefer a presentation, which gets them interact with the Product (Flavián-Blanco et al., 2011).

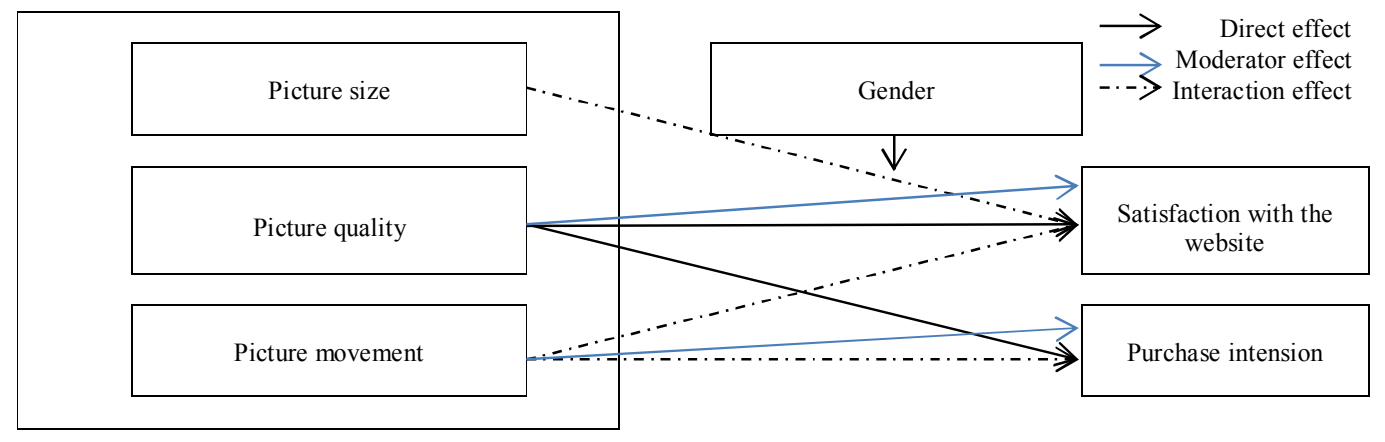

Fig. 2. The proposed model (Flavián-Blanco et al., 2011)

Simon (2000) has proposed that the less favorable perceptions of websites among women depend partly on differences in male vs. female response to site design features. Compared with men, women are much more interested in having sites provide more information. At the same time, they strongly preferred uncluttered sites with minimal graphics. Women also reported that they would rather use pull-down menus than have to click through several levels of sub-pages. In contrast, males reacted positively to sites with animated objects and extensive graphical content. Referring to the selectivity hypothesis, Simon theorized that websites may fall short in reaching the processing preferences of women if they fail to provide sufficient information or if they deliver it in a manner that does not capture female attention. If women are to perceive websites more favorably, designers may need to support more comprehensive search and evaluation.

Study of financial services websites also has detected that males were attracted to richer content, scoring higher on what was termed an 'audio/visual engagement' factor (Maltby et al., 2003). The researchers attributed the male preference for 'plenty of information', sounds, animation and graphics to a 'boys' toys' attraction but thought that females might be processing the richer content as additional interpretive cues. Subsequent focus group discussions about specific financial services sites has disclosed patterns of commentary that were interpreted as consistent with selectivity theory. Males concentrated on navigational aids, including menus and flow routes through sites. They commented favorably on headlines and concise bulleted lists but criticized sites for poor layout. They wanted to see graphical displays of financial information and appeared to be looking for decisionmaking heuristics and streamlined processing.

Women made similar comments, but also appeared to consider a wider array of site cues, including message tone, color schemes, images, font style and visual appeal. Rodgers and Harris (2003) also singled out perceptual cues such as color and graphics as potential drivers of sex differences in emotional response to websites. They reasoned that if the detailed processing style of women enhanced attention to more subtle cues and their emotional impact, women might have higher standards for site execution and experience less emotional gratification than males. The lack of social interaction may further help to explain the less favorable perceptions of online shopping among females (Andrews et al., 2007; Van Slyke et al., 2002). Some sites, such as Women.com, iVillage.com and Oxygen.com, have fostered a sense of community with chat rooms and discussion boards, while others have facilitated second-hand contact by publishing customer reviews (Garbarino and Strahilevitz, 2004). Most recently, web 2.0 technologies have fostered direct communication among consumers. However, the solitary nature of most internet shopping contributes to its 
perception among females as less advantageous and less compatible with their usual shopping behavior. The simplest description for observed gender differences in online shopping is associated with product category based. Women may seem to be more rational shoppers than men (Eastlick and Feinberg, 1994) because the purchase decisions they more frequently make (e.g., clothing) are better served by an optimizing rather than a minimizing strategy (Alreck \& Settle, 2002). Sex differences in online behavior may depend on the kinds of products purchased as they do on contrasting information processing styles (Bhatnagar et al., 2000; Rodgers \& Harris, 2003; Van Slyke et al., 2002). Products more frequently purchased by women, such as clothing and cosmetics, may be better suited to traditional shopping environments where the goods can be more easily evaluated.

\section{Research Model}

Prior literature provides the author with a rich foundation to build a research framework for the study of online customer satisfaction. Author built up a framework (Fig. 1) based on the literature review on gender difference in online customer satisfaction. The model ties together 10 factors representing three major contexts of e-satisfaction: 1) Merchandising, 3) Security, 3) Company. Key elements of this framework are discussed below:

\subsection{Merchandising}

Positive perceptions of online merchandising represent another set of elements, which could positively influences on e-satisfaction levels. This includes the number of product offerings, variety of product offering, quality of product information and quantity of product information. It seems reasonable to expect that e-satisfaction would be more positive when consumers perceive online stores to offer superior product assortments. For one, superior assortments may increase the probability that consumer requirements will be met and satisfied. This is especially likely when consumers desire items not widely distributed (e.g., specialty goods), produced in limited quantities, or unavailable at brick-and-mortar stores because shelf space is limited. For instance, a traditional book superstore may carry 150,000 titles, but an Amazon.com carries millions of titles. The probability of locating any one title, therefore, would be higher at the online store. The probability of consumers satisfying needs online would also be higher. Second, the wider assortment of products can include items of better quality that may be attractive to consumers. The lower search costs traditionally associated with online shopping are thought to result in consumers buying better quality items. Buying better quality items, in turn, can improve satisfaction by delimiting the costs of failed products. Finally, we expect richer information (more extensive and higher quality) available online to lead to better buying decisions and higher levels of e-satisfaction. Together, rich data and wide product assortments would likely lead to consumer Satisfaction with online retailing (Szymanski and Hise, 2000; Bauer et al., 2002).

$\mathrm{H}_{1}$. The relation between merchandising on online buyer satisfaction is stronger for male than female.

$h 1$ - Number of offering is scored higher for males than for females.

h2- Variety of offering is scored higher for males than for females.

h3- Quality of information is scored higher for males than for females.

h4- Quantity of information is scored higher for males than for females.

\subsection{Security}

Lack of trust is one of the most frequently cited reasons for consumers not shopping on the internet. Security and privacy have an impact on consumer trust in shopping on the internet. The 
apprehensions of the customers regarding the security for online transactions and authenticity of goods are curtailing the success of the e-tailing model. The key reason for its low acceptance is the unwillingness of people to use credit cards for online purchases. More and more sophisticated online customers would rather pay a higher price to e-tailors who provide high quality e-service. Bruskin/Goldberg Research, for example, reports that $75 \%$ of Internet shoppers emphasize credit-card security as a major consideration when deciding whether or not to buy items online (Szymanski and Hise 2000)

$\mathrm{H}_{2}$. The relation between securities on online buyer satisfaction is stronger for female than female is. $\mathrm{h}_{5}$ - Financial security is scored higher for males than for females. $\mathrm{h}_{6^{-}}$Privacy of purchase is scored higher for males than for females.

\subsection{Company}

These days we have a lot of click-and-mortar firms and it is important for them to know how their features influence on customer satisfaction and it is important for online buyer to buy his/her needs from a well-known firm and some parameters are important for them such as company size, reputation, technology, Antiquity

$\mathrm{H}_{3}$. The relation between company factors on online buyer satisfaction is stronger for men than female is.

$\mathrm{h}_{7}$-Company size is scored higher for males than for females is.

$\mathrm{h}_{8}$-Reputation is scored higher for males than for females is.

$h_{9}$-Technology is scored higher for males than for females is

$\mathrm{h}_{10}$-Antiquity is scored higher for males than for females is.

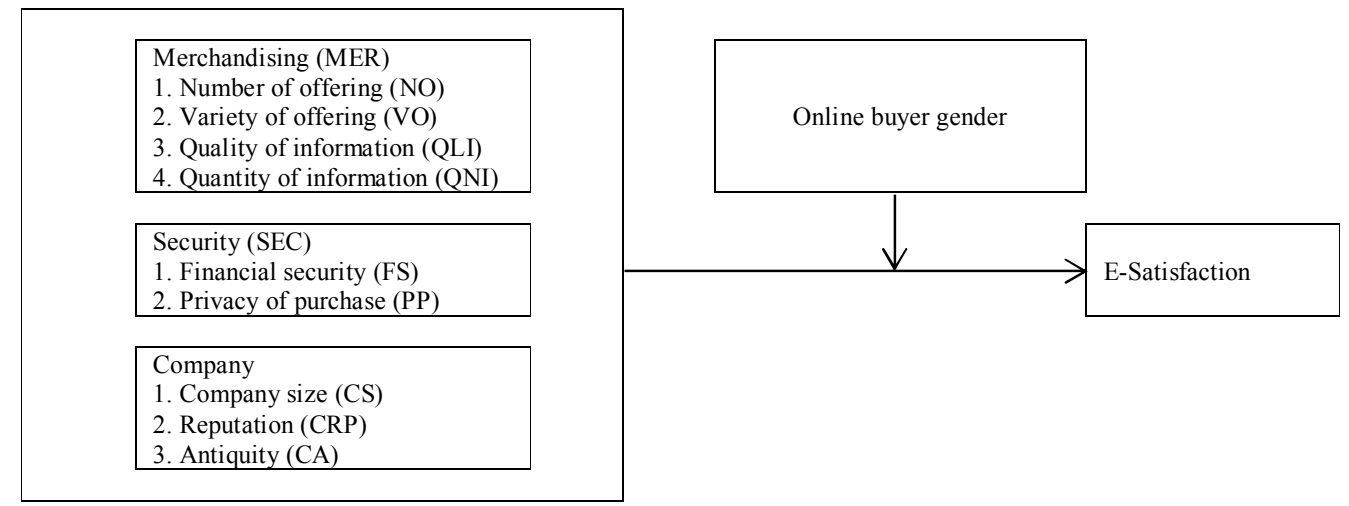

Fig. 3. Research model

Table 1 presents a comparison of different methods.

Table 1

Comparison of the research model with previous models

\begin{tabular}{lccccc}
\hline & $\begin{array}{l}\text { Flavián-Blanco } \\
\text { et al., 2011 }\end{array}$ & $\begin{array}{l}\text { Huang \& } \\
\text { Yang, 2010 }\end{array}$ & $\begin{array}{l}\text { AIMC, } \\
2009\end{array}$ & $\begin{array}{l}\text { AECE, } \\
\text { Research }\end{array}$ \\
\hline Sex (Male) & $60 \%$ & 50.6 & $57 \%$ & $51.5 \%$ & $57 \%$ \\
Age (23-45) & 64.3 & $39 \%$ & 50.3 & 61.5 & $71 \%$ \\
Internet Access per month & - & - & - & - & $54 \%$ more than 9 hour per month \\
Visit the online shop per month & - & - & - & - & $32 \% 1-5$ times per month \\
Estimated purchase cost per month & - & - & - & - & $51 \%$ less than $100 \$$ \\
\hline
\end{tabular}




\section{Research Methodology}

With the literature findings as a foundation, the quantitative phase of research reported next, focuses on gathering survey data to empirically test this e- satisfaction model. Questionnaire methodologies were chosen. In total, 100 shoppers were identified. As most of the scales are new, an exploratory factor analysis using SPSS 11 was performed on the 3-factor measurement model. All three factors are easily interpreted (see Table 1). They are financial security, merchandising and company. The data collection method was questionnaire. The method which could do this task was Factor analysis. To be sure if it is permitted to use Factor analysis or not, KMO analysis should be conducted. Since $\mathrm{KMO}$ is greater than $0.5(=0.578)$ it shows that the number of samples is big enough for using factor analysis. Moreover, since the Sig. of Bartlett's test is 0 it is permitted to use Factor analysis. For the reliability of questionnaire Cronbach's alpha was calculated .749 it means that questioner was reliable for research. To determine differences, t-tests were run on the individually observed variables within each of factors and four measures are examined:

1 item loadings

2 alpha scores and

3- Regression

4 T-Test

As shown in Table 2, values of the item loadings confirm that all items in each factor load highly on their respective factors. Alphas should be greater than 0.5

\section{Table 2}

Factors Loading for Scale Items

\begin{tabular}{|c|c|c|}
\hline Factor & Factor loading & Cronbach's alpha \\
\hline Fact 1: Merchandising & & .865 \\
\hline Number of offering & .837 & \\
\hline Variety of offering & .812 & \\
\hline Quality of information & .805 & \\
\hline Quantity of information & .808 & \\
\hline Fact 2: Security & & .875 \\
\hline Financial security & .862 & \\
\hline Privacy of purchase & .891 & \\
\hline Fact 3:Company & & .733 \\
\hline Company size & .741 & \\
\hline Reputation & .740 & \\
\hline Technology & .749 & \\
\hline Antiquity & .762 & \\
\hline
\end{tabular}

Table 3

Regression Coefficients for Predictors of e-satisfaction

\begin{tabular}{|c|c|c|c|c|c|}
\hline Predictor variable & Proposed effect & $\mathrm{F}_{\text {ANOVA }}$ & Standard coefficient (Beta) & t-value (p-level) & $\mathrm{R}^{2}$ \\
\hline Merchandising & + & 260.836 & .76 & $7.87(<.05)$ & .64 \\
\hline security & + & 224.597 & .68 & $6.27(<.05)$ & .59 \\
\hline Company & + & 222.654 & 65 & $6.17(<.05)$ & .57 \\
\hline
\end{tabular}

However, t-tests comparing the levels of each factors for men and women (See Table 4).

When examining each Merchandising items, mean scores for Female are lower than scores for men. Statistically significant differences were found between men and women regarding to merchandising. When examining each security items, mean scores for Female are lower than scores for men. Statistically significant differences were found between men and women regarding to security. When 
examining each company items, mean scores for Female are lower than scores for men. Statistically significant differences were found between men and women regarding company factors.

\section{Table 4}

Merchandising, security and company for men and women - t-tests

\begin{tabular}{lccc}
\hline Factor & Male & Female & T-test \\
\hline Merchandising & 4.16 & 3.69 & 1.86 \\
Number of offering & 3.87 & 3.48 & 1.75 \\
Variety of offering & 4.76 & 3.77 & $1.83^{*}$ \\
Quality of information & 3.65 & 3.34 & .66 \\
Quantity of information & 3.85 & 3.17 & 1.09 \\
\hline Security & 4.90 & 3.77 & 1.47 \\
Financial security & 4.61 & 3.35 & 1.06 \\
Privacy of purchase & 4.94 & 3.58 & 1.66 \\
\hline Company & 4.76 & 3.89 & 1.69 \\
Company size & 4.98 & 3.5 & $2.39^{* *}$ \\
Reputation & 3.90 & 3.5 & $1.99^{*}$ \\
Technology & 4.86 & 3.58 & 1.47 \\
Antiquity & 4.18 & 3.85 & 1.46 \\
\hline
\end{tabular}

Notes: *Significant at $0.1, * *$ significant at 0.05

\section{The results}

The objective of this exploratory research is to determine whether there are differences between genders regarding merchandising, transaction security and company factors. The respondents come from Iran where 57 percent of them were males and 33 percent were females. In addition, 50 percent of the respondents were ages $25-35 ; 21$ percent were ages of $35-45,18$ percent were ages $18-25,8$ percent were ages 45-55 and 3 percent were over age 55. The majority of the respondents were between 25-45 years old. Maybe old people desire to continue traditional methods and young generation prefer to try novel methods. Most frequently bought items of the respondents were Book and CDs with 25.2\%. In addition 23.3 Percent of the respondent bought Electronic goods, 19 percent of the respondent bought Sports equipment and 17.6 percent of them Ticket.

Regarding Merchandising, and consistent with Hypothesis1and sub hypothesis1-4, differences were detected across genders using t-tests. This finding is in line with the ANOVA analysis. It means that Merchandising on online buyer satisfaction was stronger for male than Female. Hypothesis No1 and sub hypothesis 1-4 were supported according to T-test result.

According to t-test scores for security that was reported in Table 4. Consistent with the ANOVA analysis, statistically significant differences were found between men and women for satisfaction but security was more scored for men than women. Hence, Hypothesis 4 and sub hypothesis 5-6 were supported.

Regarding company factors, and consistent with Hypothesis 3 and sub hypothesis 7-10, differences were detected across genders using t-tests. This finding is consistent with the ANOVA analysis. It means that company factors on online buyer satisfaction was stronger for male than Female. Hypothesis No 3 and sub hypothesis 7-10 were supported according to T-test result.

\section{Discussion}

E-commerce development and emergence of Electronic money, and the ability to perform business operations through internet and computerized networks have led to changes in consumers behaviors. Marketing managers gain information through analysis of consumers' behaviors. Such information assures their success in the market. Hence, examination of customer satisfaction has a critical importance, which is regarded as a means to achieve success. Marketing activities should focus on 
consumer satisfaction and issues related to that. Companies should understand the dynamic and everchanging environment they work in, and should understand the changes happening in that to adapt them with this context.

The study explored gender differences among 13 factors concerning the internet buyer. With regard to factors, the findings of this study show that Merchandise, security and company items gained more scores for men than women in online shopping in Iran.

The study found that with the development of technology, both genders seem to have equivalent resources and equal access to the internet. However, the results supported the view that the gender differences in internet shopping really exist in this generation. For male, the first three rankings of the relative importance factors of online shopping were Security, company factors, and merchandising. For female, the first three rankings of the relative importance factors of online shopping were company factors, Security and merchandising. Target market for online firms in Iran is people between 25-45 ages, Most Frequently bought item from the online retailer is Books and CDs, the second frequently bought item from online retailer is Electronic goods and the third item is Sports equipment. These findings enable internet marketers to conduct effective demographic segmentation.

\section{Implications and future research}

All these results could have important implications for online shopping which offer electronic products. Future studies could be extended in other demographic group. Moreover, the sample was drawn solely from the Iranian population. The research should be further tested using samples from other countries such as America, China, Japan and so on. Despite the limitations, this study does furnish a fertile direction for internet marketing.

The findings of this study can provide some directions for future research. First of all, one important area for future research is to explore gender differences concerning utilitarian and hedonic values of web-based shopping by culture. Consumers from different cultures have different attitudes, preferences and values, thus, consumers with different cultural background may have different attitudes toward computer-mediated consumption. It is interesting to see how the results of this study would vary in different cultural settings. Second, future researchers could investigate the differences of shopping values based on different consumer market segments (for example, age, education, income). Future research should access consumers in other contexts. Finally, the differences of shopping values between physical distribution channels and virtual web-based shopping need to be further investigated.

\section{Acknowledgement}

The authors would like to thank the anonymous referees for constructive comments on earlier version of this paper.

\section{References}

Alreck, P., \& Settle, R. B. (2002). Gender effects on Internet, catalogue and store shopping. The Journal of Database Marketing, 9(2), 150-162.

Andrews, L., Kiel, G., Drennan, J., Boyle, M. V., \& Weerawardena, J. (2007). Gendered perceptions of experiential value in using web-based retail channels.European Journal of Marketing, 41(5/6), 640-658.

Bauer, H. H., Grether, M., \& Leach, M. (2002). Building customer relations over the Internet. Industrial Marketing Management, 31(2), 155-163.

Bhatnagar, A., Misra, S., \& Rao, H. R. (2000). On risk, convenience, and Internet shopping behavior. Communications of the ACM, 43(11), 98-105. 
Davis, F. D. (1989). Perceived usefulness, perceived ease of use, and user acceptance of information technology. MIS quarterly, 13(3), 319-340.

Chiu, Y. B., Lin, C. P., \& Tang, L. L. (2005). Gender differs: assessing a model of online purchase intentions in e-tail service. International Journal of Service Industry Management, 16(5), 416-435.

Donthu, N. (2001). Does your Web site measure up?. Marketing Management, November/December, 2932.

Engel, J. F., Blackwell, R. D., \& Miniard, P. W. (1995). Consumer behavior, 8th.New York: Dryder.

Eastlick, M. A., \& Feinberg, R. A. (1994). Gender differences in mail-catalog patronage motives. Journal of Direct Marketing, 8(2), 37-44.

Flavián-Blanco, C., Gurrea-Sarasa, R., \& Orús-Sanclemente, C. (2011). Analyzing the emotional outcomes of the online search behavior with search engines. Computers in Human Behavior, 27(1), 540-551.

Francis, J. E., \& White, L. (2002). PIRQUAL: a scale for measuring customer expectations and perceptions of quality in internet retailing. In Proceedings of the 2002 American Marketing Association winter educators' conference: marketing theory and applications (Vol. 13, pp. 26370). American Marketing Association.

Garbarino, E., \& Strahilevitz, M. (2004). Gender differences in the perceived risk of buying online and the effects of receiving a site recommendation. Journal of Business Research, 57(7), 768-775.

Huang, J. H., \& Yang, Y. C. (2010). The relationship between personality traits and online shopping motivations. Social Behavior and Personality: An international journal, 38(5), 673-679.

Korgaonkar, P. K., \& Wolin, L. D. (1999). A multivariate analysis of web usage. Journal of advertising research, 39(2), 53-68.

Kalakota, R., \& Whinston, A. B. (1996). Frontiers of electronic commerce. Addison Wesley Longman Publishing Co., Inc..

Loiacono, E. T., Watson, R. T., \& Goodhue, D. L. (2002). WebQual: A measure of website quality. Marketing theory and applications, 13(3), 432-438.

Lynch, D. C., \& Rose, M. (1993). Internet system handbook. Addison-Wesley Longman Publishing Co., Inc..

Maltby, A., Chudry, F., \& Wedande, G. (2003). Cyber dudes and cyber babes: gender differences and internet financial services. Journal of Financial Services Marketing, 8(2), 152-165.

Meuter, M. L., Ostrom, A. L., Roundtree, R. I., \& Bitner, M. J. (2000). Self-service technologies: understanding customer satisfaction with technology-based service encounters. Journal of marketing, 64(3), 50-64.

Frederick, F. R., \& Schefter, P. (2000). E-loyalty: your secret weapon on the web. Harvard Business Review, 78(4), 105-113.

Rodgers, S., \& Harris, M. A. (2003). Gender and e-commerce: an exploratory study. Journal of advertising research, 43(03), 322-329.

Rodgers, S., \& Harris, M. A. (2003). Gender and e-commerce: an exploratory study. Journal of advertising research, 43(03), 322-329.

Srinivasan, S. S., Anderson, R., \& Ponnavolu, K. (2002). Customer loyalty in e-commerce: an exploration of its antecedents and consequences. Journal of retailing, 78(1), 41-50.

Szymanski, D. M., \& Hise, R. T. (2000). E-satisfaction: an initial examination. Journal of retailing, 76(3), 309-322.

Swaminathan, V., Lepkowska-White, E., \& Rao, B. P. (1999). Browsers or buyers in cyberspace? An investigation of factors influencing electronic exchange. Journal of Computer-Mediated Communication, 5(2).

Simon, S. J. (2000). The impact of culture and gender on web sites: an empirical study. ACM SIGMIS Database, 32(1), 18-37.

Urueña, A., Ferrari, A., Valdecasa, E., Ballestero, M.P., Antón, P., Castro, R., \& Cadenas, S. (2008). Estudio sobre Comercio Electrónico B2C 2008.

Van Riel, A. C., Liljander, V., \& Jurriens, P. (2001). Exploring consumer evaluations of e-services: a portal site. International Journal of Service Industry Management, 12(4), 359-377. 
Van Slyke, C., Comunale, C. L., \& Belanger, F. (2002). Gender differences in perceptions of webbased shopping. Communications of the ACM, 45(8), 82-86.

Wolin, L. D., \& Korgaonkar, P. (2003). Web advertising: gender differences in beliefs, attitudes and behavior. Internet Research, 13(5), 375-385.

Zeithaml, V. A., Parasuraman, A., \& Malhotra, A. (2000). Conceptual Framework for understanding e-service quality: Implications for future research and managerial practice.

Zeithaml, V. A. (2000). Service quality, profitability, and the economic worth of customers: what we know and what we need to learn. Journal of the Academy of Marketing Science, 28(1), 67-85. 